\title{
Vekâlet Teorisinde Fırsatçılık Kavramı ve Oyun Teorisi Arasındaki İlişki
}

\author{
The Relationship Between The Concept of Opportunism in Agency Theory And Game Theory
}

Buket ARSLAN

Doktorant, Karabük Üniversitesi,

Lisansüstü Eğitim Enstitüsü,

b.arslan86@gmail.com

https://orcid.org/0000-0001-7245-582X
Makale Başvuru Tarihi: 05.07.2021

Makale Kabul Tarihi: 23.08.2021

Makale Türü: Araştırma Makalesi

\section{Elif ÇETIN}

Doktorant, Karabük Üniversitesi,

Lisansüstü Eğitim Enstitüsü,

eliffcetin7@gmail.com

https://orcid.org/0000-0002-8051-0152

\begin{abstract}
ÖZET
Anahtar

Kelimeler:

Asimetrik Bilgi,

Fırsatçılık,

Vekâlet Teorisi,

Oyun Teorisi,

Vekâlet Teorisi ve Oyun Teorisinde ifade edildiği şekilde, finansal etkileşim içerisinde bulunan taraflar arasındaki asimetrik bilgi; avantajlı tarafin, bu avantajı kullanarak çıkar mücadelesi vermesine ve bunun sonucunda firsatçı eğilimlerde bulunmasına sebep olmaktadır. Vekâlet teorisinin temel varsayımlarından olan ve sinırlı rasyonellik ilkesi çerçevesinde içsel bir değişken olarak görülen firsatçılık kavramı, bireysel çıkarların sözleşmenin karşı tarafi aleyhinde gözetilerek ve genellikle sözleşmede bulunan boşlukları kullanarak ortaya çıkmaktadır. Bu durum asil-vekil arasında bir güven ve belirsizlik sorununa yol açmakta; bunun yanı sıra görevi kötüye kullanma, dolandırıcılık gibi hileli davranışlar neticesinde piyasa mekanizmasını etkileyebilmektedir. Bu çalışmada firsatçılık kavramı, temel mikro iktisadi analiz yöntemlerinden vekâlet teorisi ve oyun teorisi perspektifinde incelenmiş; yapılan ilişkilendirmeler doğrultusunda öneriler sunulmuştur. Yapılan çalışma ile vekâlet firsatçılı̆̆ının oyun teorisi çerçevesinde açılanabildiği görülmüş̧ür. Literatürde henüz bu iki teoriyi birlikte inceleyen bir ölçek bulunmamaktadır. Ancak çeşitli sektörlerde ortaya çıkan vekâlet firsatçıll̆̆̆ sorunlarının oyun teorisi ile çözümlenebileceği sonucuna ulaşılmıştır. Analiz araçları ve modelleme alt yapısı ile oyun teorisinin farklı senaryoları olası sonuçlarını karşılaştırarak optimal stratejileri belirleme firsatı tanıması, vekalet firsatçılığı perspektifinden yönetici ve stratejistleri önemli derecede öngörü sağlayabilecektir.
\end{abstract}

Keywords:

Asymmetric

Information,

Opportunism,

Agency Theory,

Game Theory,

\section{ABSTRACT}

As expressed in Agency Theory and Game Theory, the asymmetric information between the parties in financial interaction causes the advantageous party to enter into a struggle for interest by using this advantage and as a result, show opportunistic tendencies. The concept of opportunism, which is one of the basic assumptions of the agency theory and seen as an internal variable within the framework of the limited rationality principle, emerges by putting individual interests forward against the counterparty of the contract and generally using the gaps in the contract. This situation causes a problem of trust and uncertainty between the principal and the agent, as well as adversely affecting the market mechanism as a result of fraudulent behaviors such as professional misconduct and fraud. In this study, the concept of opportunism is examined from the perspective of agency theory and game theory, which are among the basic microeconomic analysis methods; and suggestions are made in line with the established associations. With the study, it has been seen that agency opportunism can be explained within the framework of game theory. There is no scale in the literature that examines these two theories together yet. However, it has been concluded that the problems of proxy opportunism that arise in various sectors can be solved with game theory. Due to analysis tools and modeling infrastructure of game theory provides the opportunity to determine the optimal strategies by comparing the possible outcomes of different scenarios, it will be be able to provide significant insight to managers and strategists from the perspective of agency opportunism. 


\section{GIRISS}

Vekâlet teorisi, asil-vekil ilişkisi üyelerinin kişisel çıkarları ve bunların bir organizasyon içindeki çözümü etrafında gelişmiştir. Asil-vekil ilişkisinin sosyal çerçevesi, vekile organizasyon yapısının kısıtlamaları dâhilinde hareket etme özgürlüğü sunsa da bir organizasyonun üyelerinin farklı motivasyonları vardır ve eylemleri kendi çıkarlarına hizmet olarak algılanabilmektedir (Baker, 2019:304). Yönetim ve ekonomi literatüründe oldukça eski teorilerden biri olarak belirtilen vekâlet teorisi, organizasyonların sahiplerinin ve yöneticilerinin ayrılması nedeniyle ortaya çıkan sorunları araştırarak, sorunların azaltılmasına vurgu yapmaktadır. Bu teori, organizasyonlarda vekillerin eylemlerini düzenlemek için farklı yönetim yapılarının uygulanmasına yardımcı olmaktadır.

Vekâlet sorunlarından en önemlileri; çıkar çatışması, bireysel menfaatler, fırsatçılık, izleme ve vekâlet maliyetleri, bilgi asimetrisi, ahlaki tehlike ve tersi seçim ve riskten kaçınma olarak belirtilebilmektedir. Vekâlet teorisinde asil-vekil arasındaki sorunlardan bilgi asimetrisi, çeşitli firsatçıllk sorunlarına neden olabilmektedir. Fırsatçılık eğilimi genellikle asil-vekil arasındaki çıkar çatışmaları söz konusu olduğunda gerçekleşmektedir. İlgili davranış, kişilerin aldatma eğilimini, hile ve hırsızlık gibi faaliyetleri de içerebilmektedir.

Oyun teorisi ise, birden fazla karar vericinin olduğu ve bir karar vericinin seçiminin kalitesinin hem bu seçime hem de diğer karar vericilerin seçimlerine bağlı olduğu karar problemleri üzerine yapılan çalışmalar olarak belirtilmektedir. Öncelikle ekonomi alanında matematiksel bir model olarak geliştirilen oyun teorisi, insanların karar verme davranışını incelemek için çeşitli disiplinlere yaygın olarak uygulanmıştır. Genel olarak oyun teorisi, tüm rakiplerin rasyonel olduğunu varsayarak, karar vericilerin belirli rakip stratejileri altında daha iyi sonuçlar elde etmek için kendi kazançlarını maksimize etmeleri şeklinde tanımlanabilmektedir.

Oyun teorisinin vekâlet sorunlarını açıklayabilmesi ve çözüme ulaştırabilmesi konusunda literatürdeki boşluğu doldurabilme amacıyla hazırlanan bu çalışmada çoğunlukla bilgi asimetrisinden kaynaklanan vekâlet firsatçılığ sorununa, tanımlayıcı araştırma metodu ile inceleme ve analizler yapılarak değinilmiştir.

\section{VEKÂLET TEORİII}

\subsection{Tanımı ve Kuramsal Çerçevesi}

Vekâlet ilişkisi, bir veya daha fazla asilin karar verme haklarını; birtakım görevleri kendi adlarına yerine getirmeleri için vekil olarak belirledikleri başka kişi/kişilere devrettikleri bir sözleşme olarak tanımlanabilmektedir (Jensen ve Smith, 2000:97). Bahsi geçen ilişki; aktörlerden vekil olarak tayin edilen kişinin, asil olarak tayin edilen kişiyi temsilen, sınırları belirlenmiş sorunlara ilişkin faaliyetlerde bulunması ile söz konusu olmaktadır (Ross, 1973:134). Oldukça geniş bir kapsamda örneklendirilebilen vekâlet anlayış1, devlet-yurttaş veya işçi-işveren arasında gerçekleştirilebilecek anlaşmalara dayalı olan bütün düzenlemelerin unsurlarını içerebilmektedir (Ross, 1973:134). Örgüt kapsamında incelendiğinde vekâleti veren asil (pricipal) olarak paydaş, vekil (agent) olarak yönetici arasında bir temsil ilişkisi bulunmaktadır. Vekâleti devredenler, anlamlı sonuçlara erişebilmek için vekillerin desteğine ihtiyaç duymaktadır (Ataman, 2009:226).

Vekalet teorisi asil ve vekil arasındaki ilişkileri düzenleyen optimal sözleşmeyi belirlemeye odaklanmaktadır (Eisenhardt, 1988:490). Vekâlet teorisinin klasik tanımlamasında Jensen ve Meckling (1976), çoğu örgütün basit hukukî kurgular olduğu ve bireyler arasında sözleşme ilişkilerinin belirteci olan bir bağ tebliğ ettiğini iddia etmektedir. $\mathrm{Bu}$ bağlamda vekâlet ilişkisinin unsurları, vekâlet masraflarını azaltmak için gerçekleştirilen sözleşmeler, izleme araçları ve diğer sosyal kontrol türlerinden meydana gelmektedir (Shapiro, 2005:266).

Dışa kapalı aile şirketleri ve şahıs ortaklıklarında, sahiplik ve yöneticilik ayrımı olmaması sebebiyle vekâlet ilişkisinden bahsedilemez. Fakat bu ilişki, halka açık anonim şirketlerin yöneticileri ve pay sahipleri arasında oldukça yüksek düzeyde gözlenebilmektedir (Ataman, 2009:226). Dolayısıyla ancak sahiplik ve yönetime ilişkin bir ayrımın olduğu yapılarda asil-vekil ilişkisinden söz edilebilmektedir (Maher ve Andersson, 2000:2). $\mathrm{Bu}$ ayrım ise çoğunlukla çıkar çatışmalarını beraberinde getirmektedir.

Vekalet teorisine göre, şirket sahibini temsil eden yöneticiler, kimi zaman asilin refahı üzerinde risk yaratma karşılığında eylemleri kendi çıkarları doğrultusunda gerçekleştirebilmektedir (Gaur vd., 2015:913). Zira McGregor'ın X Teorisi'nde ifade ettiği üzere bireyler öz çıkarlarının peşinde koşma ve kişisel mutluluklarını maksimize etme eğilimindedirler ve rasyonel ekonomi modeline dayanan bu durumun potansiyel firsatçı davranışları olarak ortaya çıkması mümkündür (Donaldson, 1990:371). Bu bağlamda vekâlet teorisinin temel 
ilgi alanını, asil-vekil ilişkisindeki çıkar farkından doğan çatışmaları engelleyebilmek için alternatif yönetişim yapıları, denetim ve önlemlerin tespit edilip; uygulanması oluşturur.

Vekâlet teorisi, pozitivist yaklaşım ve asil-vekil yaklaşımı olmak üzere iki ayrı anlayış kapsamında incelenmektedir. Bu iki yaklaşımın ortak bir analiz birimi bulunmaktadır; asil ile vekil arasındaki sözleşme. Yine kişiler, kuruluşlar ve bilgiler hakkında da ortak varsayımlarda bulunmalarına karşın iki yaklaşım; matematiksel titizlikleri, bağımlı değişkenleri ve biçimleri bakımından farklılık göstermektedirler (Eisenhardt, 1989:64).

Jensen ve Meckling'in (1976) ampirik analiz ve pratik önlemler sunduğu (Rosanas, 2008:448) çalışmayı esas alan pozitif vekalet teorisinin metodolojisi, organizasyonel formların seçilme şekline dayanmakta ve üç temel varsayıma odaklanmaktadır. Bunlar (DuMoutier, 2010:130);

- Belirli (kolayca aktarılamayan) bilginin varlığı,

- Tarafların hem asil hem de vekil rollerini üstlendiği iki veya çok taraflı bir vekâlet ilişkisi,

- Karar haklarının bunları en iyi şekilde geliştirebilecek taraflarca edinilmesi olarak ifade edilmektedir.

Pozitivist vekâlet yaklaşımının önermelerinde, asil ve vekilin çıkar uyumlarının tespiti için sözleşme türünün önemi vurgulanmakta ve sözleşmeyi oluşturacak ögelerin etkilerine dikkat çekilmektedir. Bunlar; bilgi asimetrisi, vekil ve asilin risk ve çaba konularındaki seçimleri, sermaye yoğunluğu, örgüt içi ve dış çevre işgücü piyasalarının sahip olduğu özellikler, izleme ve bağlanma maliyetleri şeklinde açıklanmaktadır (Kurland, 1995:466).

Pozitivist vekâlet yaklaşımı vekillerin kendi çıkarlarına yönelik davranışlarını önlemek ve vekâlet problemlerini çözmek üzere bilgi sistemlerini önermektedir. Bu önermeye göre bilgi sistemleri, vekilin neyi nasıl yaptı̆̆ konusunda asili bilgilendirdiğinden; vekilin firsatçı davranışlarını azaltabilmektedir. Zira bu sayede vekilin, asili yanıltamayacağının farkında olması beklenmektedir (Eisenhardt, 1989:60). Diğer bir vekâlet teorisi akımı olarak bilinen asil-vekil yaklaşımı ise, işveren-işçi veya tedarikçi-satıcı ilişkilerine odaklanmaktadır (Hamilton ve Kashlak, 1999:169). Asil-vekil yaklaşımında, hiyerarşik bir etkileşim içerisinde bulunan taraflar arasındaki sözleşmedeki üç unsurun modellemesine yoğunlaşılmıştır. Bunlar (Jensen, 1983:345);

- Sözleşme taraflarının tercihlerinin yapısı,

- Belirsizliğin doğası,

- Çevredeki bilgi yapısı şeklinde sıralanmıştır.

Vekilin asil yerine eylemde bulunmasıyla doğan asil-vekil ilişkisinde, bilinmeyen ve gözlemlenemeyen bazı vekil davranışları söz konusu olabilmektedir. Buna tabi olarak vekilin, uygulamalar konusunda asilden daha fazla bilgi sahibi olması, asil-vekil sorununu ortaya çıkarmaktadır. Bu durumda vekilin, asil çıkarlarını dikkate almaksızın, aldatma yöntemi veya oportünist tercihler ile kendi çıkarları doğrultusunda hareket etmesi mümkündür. Bahsi geçen asil vekil sorunu karşısında vekâlet yaklaşımı üç tür davranışa odaklanmaktadır. İlk olarak vekilin, asilin amaçlarını gerçekleştirmesine yönelik telkin edilmesi yöntemi tercih edilebilir.

$\mathrm{Bu}$ yöntem, vekilin örgüt için önemli ve karar alma proseslerinde etkili biri olduğunu vekile hissettirerek motivasyon kazandırmayı amaçlar. Bir diğer durumda, vekilin direkt olarak yönetim tarafından zorlayıcı emirler ile kontrol altında tutulması söz konusudur. Yöneticilerin talimatlarını gerçekleştiremeyen vekil, asilin kılavuzluğunda yardım alabilir veya asil, vekili cezalandırma yöntemine başvurabilir. Son olarak da vekil, kendi adına ancak asilin çıkarları doğrultusunda temin edilen teşvik ve kuralları takip ederek asilin kazancını artırması sonucunda bir performans ödemesi almayı hedefleyebilir (Mirrlees, 1999:3).

Vekalet teorisi davranış odaklı sözleşmeleri daha fonksiyonel olduğunu düşünmekte ve asil-vekil arasında gerçekleşecek sözleşme sisteminin davranış merkezli ve optimal olmasına odaklanmaktadır. Buna göre vekilin ücretlendirilmesi eylemlerine sonucuna göre yapılmakta ve bu sayede vekil performansı öne çıkarılmaya çalışılmaktadır. Dolayısıyla eylemlerine uygun olarak ücretlendirilen vekilin çıkarları, asilin çıkarının en üst seviyeye geldiği noktada maksimize olacaktır. Bu sayede asilin, kendi kazancı yükseldikçe vekili daha olumlu yönde değerlendirmesi ve vekilin eylemlerine direkt müdahale firsatı kazanması söz konusu olacaktır. Asil-vekil yaklaşımı çerçevesinde, taraflar arasındaki çıkar çatışması, vekilin asile kıyasla daha çok risk alma eğiliminde olması ve sistemin kazandığı ve kolay ölçülebilen gelir kapsamında kurulu üç temel çatı bulunmaktadır. Taraflar arasındaki çıkar çatışması rasyonel insan varsayımına dayanmakta ve bu durum sistem içerisinde birtakım çatışmaların doğmasına dikkat çekmektedir. Ekonomik alanda faaliyet gösteren örgütler gelir elde etme amacı güttüğünden, öğütün başarısı nihai gelire ulaşma kapasitesi ile ölçülmektedir. Son olarak tarafların farklı risk 
algılarına sahip olması şunu anlatmaktadır: Vekilin rahatlıkla iş değiştirme şansının olmayışı risk alma eğilimini yükseltirken; asilin ise kolay bir şekilde başka bir alana yönlendirebilme şansına sahip olduğu yatırımlar risk alma eğilimini düşürmektedir (Aksoy, 2010:47). Yine de asil vekil teorisi, karmaşık insan davranışları ve firsatçı yaklaşımları yorumlamak için yetersiz olduğu konusunda eleştiri almaktadır. Kimi araştırmalara göre yönetsel motivasyonunun sadece fırsatçı davranışlar ile açıklanması sosyal var oluşun gerçekleriyle uzlaşmamaktadır.

\subsection{Asil-Vekil Davranışlarına İlişskin Temel Varsayımlar}

Vekâlet teorisinde asil-vekil davranışlarına ilişkin temel varsayımlar rasyonellik, ahlaki tehlike, tersi seçim, bilgi asimetrisi ve firsatçıllk çerçevesinde değerlendirilmektedir. Vekâlet teorisine göre, bireyler kendi çıkarlarını maksimize etmeyi hedefleyen rasyonel insan davranışı sergilemektedir. Bu noktadan hareketle gerek vekil gerek asillerin, minimum gider ile maksimum kazancı arzuladıkları söylenebilir.

- Rasyonalite: Vekâlet teorisini meydana getiren asil-vekil ve pozitif vekâlet yaklaşımları, iktisadın rasyonel ve şahsî çıkarları maksimize etmeyi planlayan bireyler biçiminde açıkladığı homo economicus varsayımını esas almaktadır (Ghoshal, 2005:82). Bu varsayıma göre; insan gerçek insan kavramından farklıdır. İfade edilen tanım, arzu ve tercihlerini açıkça aktarabilen avantaj haritalarına sahip ve çıkarcılık temelli sınırsız rasyonaliteleri ile bahsi geçen arzu ve tercihlerini doyurmaya çalışan varlıklardan bahsetmektedir.

Teoride asilin mümkün mertebe yüksek refaha sahip olabilmesinin temel koşulu vekilin refahının düşük olmasına tabi görülmektedir. Pareto teorisi anlamındaki etkinlik teorinin ana amacıdır. Bu amaç vekile yapılan harcamalarda verimsizliği dışlayarak asile fayda sağlayabilir. Fakat bütün teori vekilin ücret sistemini tasarlayan asil hakkındadır. $\mathrm{Bu}$ yüzden asil farklı etkili/verimlilik kombinasyonları arasından birisini seçerek üstünlük sağlamaktadır. Daha sonraları daha karmaşık modeller diğer değişkenleri modellerine dâhil etmişlerdir. Fakat onların resmi modeli kullanarak eriştikleri oldukça sınırlıdır. Tanılama ve bağlılık gibi rasyonellikte Simon (1947) tarafından dikkate alınmış olan değişkenler veya "diğer insanların refahını önemseme" vekâlet teorisi tarafından dikkate alınmaz. Birey, mekanik fayda fonksiyonları olarak tasvir edilmişse bile elde etmek istedikleri faydalar aynı zamanda onların niyetlerini de yansıtmaktadır (Rosanas, 2008:448-449).

- Bilgi Asimetrisi: Kusurlu veya yetersiz bilgiden kaynaklanabilen bilgi asimetrisi kavramı; bilgi avantajına sahip tarafın, bahsi geçen avantajı karşı taraf alehine kullanması halinde birtakım sorunları ortaya çıkarmaktadır. Asimetrik bilgi, eylemler gerçekleştirilmeden önce, sözleşmenin imza aşamasında ex-ante veya imza sonrasında ex-post biçimde kendini gösterebilmektedir. Ex-ante durumların çoğunlukla tersi seçim şeklinde sonuçlandığı bilinmektedir. Tersi seçim sorunu, taraflar arasında gerçekleşecek sözleşmenin öncesinde beliren ve taraflardan birince bilginin gizli tutulmasından kaynaklanmaktadır. Gizli bilgi, sözleşmeye taraf olanlardan birinin kendisi hakkında biliyor olduğu, diğerinin öğrenmek istediği ancak edinemediği bilgiyi ifade eder. Ahlaki tehlike (gizli eylem) ise sözleşme tamamlandıktan sonra ex-post olarak meydana gelen ve gizlenen bir eylem sonucunda söz konusu olan bilgi asimetrisidir (Mesjasz, 2008:133).

- Firsatçılık: Kavram, vekâlet teorisi kapsamında diğer bir ifade ile asilin vekile yetki vermesi halinde değerlendirilirse teori; vekil çıkarlarının asille çatışması durumunda vekilin fırsatçı davranacağı varsayımından doğan sözleşmeye dayalı sorunları açığa çıkarmayı hedeflemektedir (Sharma, 1997:760). Bireylerin firsatçı ve bencil varlıklar olduğu fikri vekâlet teorisinin dayandığı temel varsayımlardandır. Vekâlet teorisi, taraflar arasında amaç uyumsuzluğu bulunan durumlarda örgütler açısından bu uyumsuzluğun nedenleri ve sonuçları hakkında bilgi edinmeye çalışmaktadır. Dolayısıyla vekâlet teorisi bireysel çıkarları düşünme davranışını temel alan bir teoridir. Buna göre, kişiler kendileri için en avantajlı davranışlarda bulunmakta ve bu durum bireylerin sahip oldukları diğer seçenekleri hayata geçirme ihtimalini ortadan kaldırmaktadır. Fırsat maliyeti veya alternatif maliyet şeklinde tanımlanan bahis konusu durum, tercih edilenin değeri ile optimal alternatifi arasındaki farkı ifade etmektedir. Bu sebeple alternatif maliyet için, alınan kararların nispi öneminin bir belirtisi olduğu söylenebilir. Bireye özgü tutumların analizine özen gösteren vekâlet teorisi, asil-vekil arasında gerçekleştirilen sözleşmemin etkin şekilde uygulanmasına destek olmaktadır (Kahveci, 2008:25). Fırsatçılık içeren tutumlar, tarafların

1 Pareto etkinliğinde, bir toplumda üretim ve tüketimin yeniden dağıtımı yapılarak bir kimsenin refahı arttırılmak istendiğinde, eğer başkalarının refahını düşürmeden bunu sağlama olanağı bulunmuyorsa, o toplumda etkin kaynak dağılımının sağlandığını belirtilmektedir (Seyidoğlu, 2006:390). 
imzaladıkları sözleşmeye bağlı kalmamalarına neden olabilmektedir. Taraflardan birinin, sözleşmenin karşı tarafına kayıplar yaşatmasına karşın, kendi çıkarları doğrultusunda ve kasıtlı olarak bulunduğu aldatmaya yönelik eylemleri tanımlayan firsatçılık kavramı şu şekilde örneklendirilebilir; Tarafların imzaladığı sözleşmenin hayata geçirilmesi sırasında ön görülmemiş bir durum meydana geldiğinde, her iki taraf da sözleşmeye bağlı kalmaksızın bireysel çıkarlarını artırmak üzere uğraşacaklardır. Böyle bir durumda, tarafların sahip olduğu asimetrik bilgi nedeniyle sözleşmeye riayet edilip edilmediğini denetlemek son derece güçtür (Gassenheimer vd., 1996:69).

- Ahlakî Tehlike: sözleşmeye taraf olanlardan birinin, sözleşmeden diğeri aleyhine yararlanacak şekilde davranış geliştirmesi sonucunda oluşan durumu açıklamaktadır. Diğer bir ifade ile ahlakî tehlike; taraflardan birinin maliyetleri karşı tarafa yükleyerek fayda sağlamaya çalıştığı ve bunu yapabilmek için firsata sahip olduğu koşullarda ortaya çıkmaktadır (Seyidoğlu, 2006:384). Buna yol açan kritik nedenlerden biri sözleşmeye bağlı tarafların bir ürün veya hizmetin niteliklerine ilişkin farklı bilgilere sahip olmasıdır. Asil adına eylemde bulunmak amacıyla sözleşme yapan vekil, asilin gözlemleyemediği ve ispatlayamadığı eylemleri gerçekleştirerek sözleşmeye ters düşmektedir. Asil-vekil arasında var olan asimetrik bilgi ne derece büyük ise bunun sonucunda doğması beklenen kayıplar da o derece fazla olacaktır.

- Tersi Seçim: Gizli bilgi (hidden information) sebebiyle ortaya çıkan tersi seçim sorunu işlemlerin gerçekleşmesinden önce meydana gelmektedir. Bu duruma örnek olarak ikinci el araç piyasasına ilişkin bir yaklaşım bulunmaktadır. Buna göre, alıcıların araçların kalitesi ve fiyatı konusundaki tahmini davranışı toplum içinde genellenecek ve kalite sinyali olarak algılanacaktır. Buna göre yüksek fiyat iyi kalite sinyali olarak, düşük fiyat ise kötü kalite sinyali olarak algılanacaktır. Ancak kesin olmayan bilgilere dayanılarak yapılan söz konusu tahmini kalite sinyali, piyasanın işleyişini bozan bir unsurdur. $\mathrm{Bu}$ durumun bir sonucu olarak, düşük kalite sinyali sebebiyle yüksek kaliteli araçlar piyasadan çekildiğinde göz ardı edilmeyecek bir piyasa etkinsizliği ortaya çıkacaktır. Diğer taraftan, zorunluluğa bağlı olarak yüksek kaliteli bir aracın düşük kalite sinyali ile ucuza satılması da bir piyasa etkinsizliğidir (Akerlof, 1970:488-500).

\subsection{Vekâlet Maliyetleri}

Vekilin kendi çıkarlarının, asilin çıkarlarını önlemesi ihtimalinin düşürülmesi için; vekilin izlenmesi sonucunda doğan maliyetler vekâlet maliyetleri şeklinde sınıflandırılmaktadır. Jensen ve Meckling (1976:308) vekâlet maliyetlerinin izleme maliyetleri ile sınırlı olmadığını ve izleme maliyetlerine ek birtakım maliyetleri de içerdiğini belirtmektedir. Yazarlar vekâlet maliyetlerini, asilce üstlenilen izleme maliyetleri, vekil tarafindan katlanılan bağlanma (tazmin edici/garanti sağlayıcı anlaşma) maliyetleri ve iki tarafça da yüklenilen artık/önlenemeyen kayıplar olarak sınıflandırmıştır.

Şekil 1: Vekâlet İlişkilerinin Etkileri

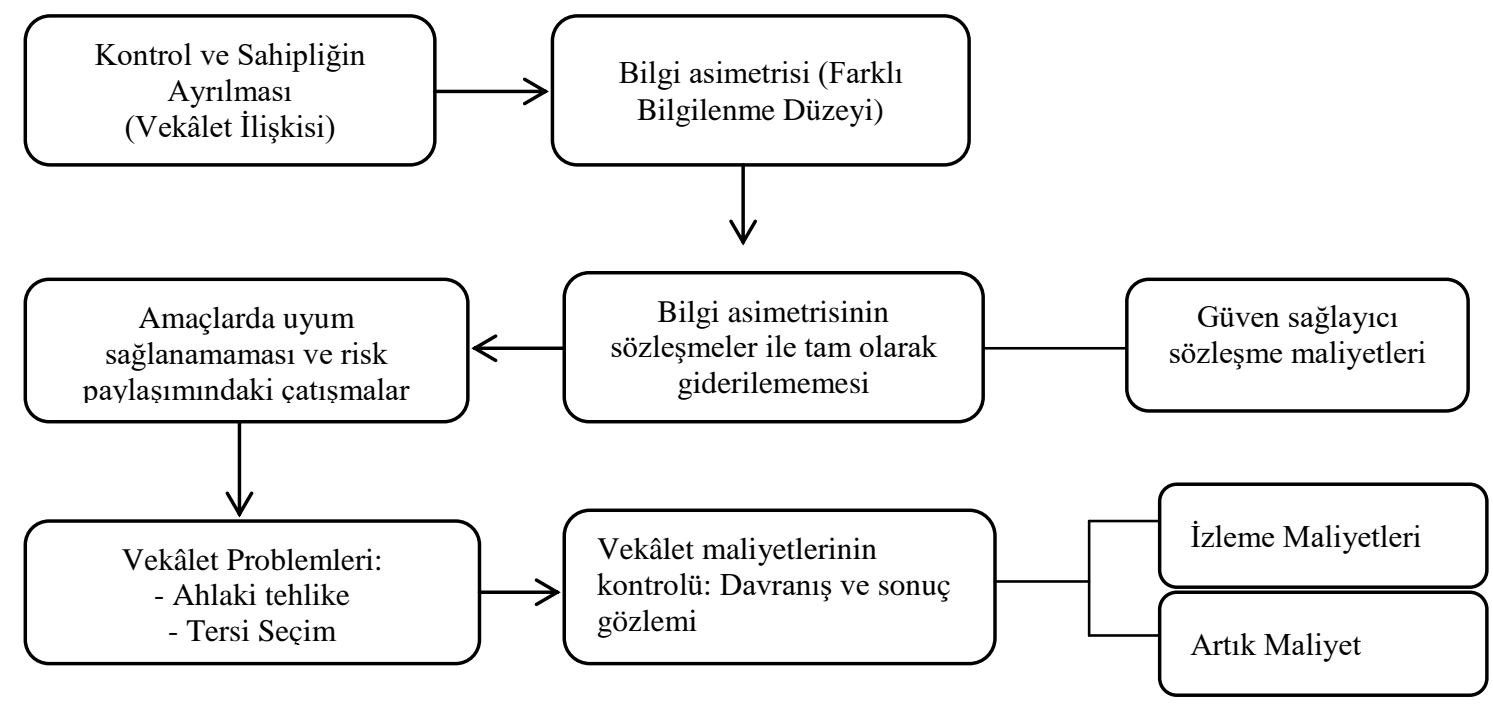

Kaynak: Mark Van Osnabrugge, 2000:96. 
- İzleme Maliyetleri: İzleme maliyetleri; asilin, vekilin davranışlarını ölçmek, gözlemlemek ve denetlemek amacıyla katlandığı giderleri ifade eder. Bu maliyetler; denetim maliyetlerini ve yöneticilerin işten çıkarılması sonucundaki ortaya çıkacak tazminat maliyetlerini kapsamaktadır (McColgan, 2001:5). Vekilin izlenmesi için uygulanan temel yöntem, yöneticiler tarafindan vekil performanslarının değerlendirildiği raporların düzenlenmesidir. Genellikle finansal niteliği bulunan bu raporların değerlendirilmesi için gerekli teknik bilgiye sahip olmamaları nedeniyle gerek pay sahiplerinin denetçi görevlendirmesi, gerekse bu ve benzeri raporlar için harcanan zaman, izleme maliyeti olarak değerlendirilmektedir (Turaboğlu, 2004:119).

- Bağlanma Maliyetleri: Vekilin eylemlerinin incelenmesi ve yönetilmesi için asile yardım sağlayamasa da bağlanma maliyetleri, görevin yerine getirildiğine dair bir garanti temin etmektedir (Hannes, 2007:1439). Özetle bağlanma maliyetleri, vekilin gerçekleştirdiği eylemlerin asile fayda sağlayacağını garantilemesinden hareketle oluşmaktadır (Woo vd., 1992:433). Bağlanma maliyetleri asilin, vekilin gerçekleştirmiş olduğu eylemlerini daha güncel, sık ve direkt bilgilendirmesi ve dolayısıyla asilin vekilin hareketlerini bu sayede daha iyi anlaması yoluyla azaltılabilmektedir. Eisenhardt (1989) davranış odaklı sözleşmelerin kullanılmasının vekiller üzerinde daha geniş bir kontrol imkânı sağladığını belirtmektedir. Bu tür kontroller amaçlara ulaşmak için kullanılan süreçlere odaklanabilir. Kontroller büyük olasılıkla girdi ve çıktıları, kısa ve uzun dönem amaçlarını, nicel ve nitel kriterler olarak içermektedir. Bu sözleşmelerin yönetsel faaliyetler açısından geniş bir alan sunduğu ve daha yüksek bir yönetsel efor ve etkililik sağladığını belirtilmektedir (Woo vd., 1992:436).

- Önlenemeyen Kayıplar/Artık Maliyet: Etkili bir bağlanma ve izleme maliyetine katlanılsa dahi kimi zaman ek kayıplar söz konusu olabilmektedir (Islam vd., 2010:180). Diğer bir ifade ile vekâlet sorunlarını azaltmak maksadıyla katlanılan maliyetler kimi sorunları tam anlamıyla çözememektedir. Önlenemez kayıplar biçiminde ifade edilen söz konusu kayıplar, genellikle bağlanma ve izleme yöntemleri ile yönlendirilmiş olan vekilin tutumlarının asilin faydasına olduğu garantisini verememesinden doğmaktadır.

- Güvence Să̆layıcı Sözleşme Maliyetleri: Asiller vekillerin kendileri yararına hareket etmelerini kontrol edecek yapılar kurmakta ve böyle olmazsa vekilden bunun tazmin etmektedirler. Bu sistemlerin kurulması ve onlara bağlı kalınması maliyeti, güvence sağlayıcı sözleşme maliyeti olarak adlandırılmaktadır. Vekil tarafından katlanılan bu maliyetler her zaman finansal olmayıp hissedarlara ek bilgi vermeyi de kapsayabilir. İzleme maliyetindeki marjinal azalma, güvence sağlayıcı sözleşme maliyetindeki marjinal artş̧a eşit olduğunda vekiller bu maliyete son vermektedirler (McColgan, 2001:6).

\section{OYUN TEORİSI}

Oyun teorisi, rasyonel bağımsız karar vericiler olarak tanımlanan oyuncular arasındaki etkileşimlerin incelenmesi ve analizine yönelik uygulamalı matematiğin bir dalı olarak belirtilmiştir (Abdel-Raouf vd., 2020:26). Oyun teorisi kavramları, farklı stratejik senaryoları formüle etmek, yapılandırmak, analiz etmek ve sonunda anlamak için ortak bir dil sağlamaktadır. Oyun teorisi, çatışma durumlarını, oyuncular arasındaki etkileşimi ve oyuncuların kararlarını araştıran bilimsel bir disiplindir (Bhuiyan, 2016:114).

Oyun teorisi, karar verme sistemlerinin davranışını modelleme ve değerlendirme bilimi olarak da tanımlanabilmektedir. Oyun teorisi, bir sistemin matematiksel davranışını stratejik veya oyun temelli bir şekilde elde etmeye çalışmaktadır. Oyun teorisinin amaçlarından biri, karar verme oyunlarının olası olaylarını tahmin etmektir (Sohrabi ve Azgomi, 2020:59).

Oyun teorisi, karar alma süreçlerinde iki ya da daha fazla oyuncunun bulunduğu ve oyuncuların alacakları kararlarda diğer oyuncuların da etkisinin göz önünde bulundurulduğu, çeşitli alanlarda uygulanabilen stratejik bir yaklaşım olarak tanımlanabilmektedir.

\subsection{Oyun Teorisi Gelişimi}

Oyun teorisi, 20. yüzyılın başlarında formel bir disiplin olarak geliştirilmiştir. 1928'de matematikçi John von Neumann tarafından iki kişilik işbirlikçi olmayan sıfır toplamlı bir oyun önerilmiştir. Daha sonra 1944'te oyun teorisinin gelişimini simgeleyen Oyunlar ve Ekonomik Davranış Teorisi (Theory of Games and Economic Behavior) kitabı John von Neumann ve ekonomist Oskar Morgenstern tarafından yazılmıştır. 1950'lerde, 
işbirlikçi oyun teorisi en üst seviyeye ulaşmış ve işbirlikçi olmayan oyun teorisi de gelişmeye başlamıştır (Zhang ve diğerleri, 2010: 152). Bu sürede, John F. Nash 1950 ve 1951 yıllarındaki makalelerinde işbirlikçi olmayan oyunlar için stratejik çözüm olarak adlandırdığı denge kavramını (Nash Dengesi) ilk defa kullanmıştır (Abdel-Raouf vd., 2020:26).

Oyun teorisi öncelikle yaygın olarak ekonomide kullanılmıştır. Daha sonra, siyaset, ordu, biyoloji, mühendislik, felsefe, ulaşım, bilgisayar bilimi gibi diğer alanlarda uygulanmıştır (Zhang vd.,, 2010:152). Çeşitli disiplinlerde karmaşık süreçleri modellemek ve analiz etmek amacıyla kullanılabilir olması oyun teorisini güçlü bir araç haline getirmektedir (Abdel-Raouf vd.,, 2020:26).

\subsection{Oyun Teorisinin Temel Kavramları}

Oyun teorisinin temel kavramlarını; oyun, oyuncu, durum, eylem, kazanç, strateji ve denge oluşturmaktadır. Yine Nash Dengesi de oyun teorisinde bilinmesi gereken temel kavramlardan birisidir.

- Oyun: Oyun, varlıklar veya varlık grupları arasındaki etkileşim durumunun bir modeli olarak tanımlanmaktadır (Sohrabi ve Azgomi, 2020:60).

- Oyuncu: Oyuncular, oyunların temel varlıklarıdır. Bu varlıklar; bir kişi, bir topluluk, bir kavram olabilen oyunda karar vericiler olarak tanımlanmaktadırlar (Sohrabi ve Azgomi, 2020:60). Diğer bir ifadeyle, birbirleriyle rekabet içerisinde olan ve kendi çıkarlarına göre stratejilerini gerçekleştiren karar alıcılar oyuncu olarak adlandırılmaktadır (Demirci ve Palanc1, 2019:532).

- Durum: Durumlar, oyuncuların içinde bulunabileceği olası oyun durumları olarak tanımlanmaktadır (Sohrabi ve Azgomi, 2020:60).

- Eylem: Oyuncuların farklı durumlarda yapabildikleri tüm olası eylemler olarak belirtilmektedir (Sohrabi ve Azgomi, 2020:60).

- Kazanç: Bir oyuncunun bir oyundaki veya oyunun bir adımındaki eylemine verilen puana, olumlu veya olumsuz olabilen kazanç adı verilmektedir (Sohrabi ve Azgomi, 2020:60). Kazanç kavramı, sayısallaştırılabilen her türlü fayda olarak tanımlanabilmektedir (Hoş, 2020:50).

- Strateji: Bir oyuncunun stratejisi, oyuncunun oyunun her durumunda yapabileceği bütün eylemler dizisini kapsamaktadır. Her oyuncunun koşullara ve hedeflere göre seçilebilecek stratejileri bulunmaktadır (Sohrabi ve Azgomi, 2020:60). Stratejiler saf strateji ve karma strateji olarak ikiye ayrılmaktadır (Hoş, 2020:40).

- Denge: Hiçbir oyuncunun bir oyunda değişme eğiliminde olmadığı noktadır ve herhangi bir değişiklik, tüm oyuncuların getirilerinin bozulmasına neden olmaktadır (Sohrabi ve Azgomi, 2020: 60).

Nash dengesi, oyun teorisindeki temel kavramlardan biri olarak belirtilmektedir. Nash dengesi, diğer oyuncuların stratejisini değiştirmek istememesi durumunda herhangi bir oyuncunun stratejisini değiştirerek daha fazla kazanç sağlayamayacağı bir oyun noktasıdır (Nezarat ve Dastghaibifard, 2015:12).

Stratejik bir oyunda, hiçbir oyuncunun faydalar açısından tek taraflı olarak eylem eğiliminde bulunmadığı bir durumdur. Hem saf strateji hem de karma strateji ile Nash dengelerini tanımlamak mümkündür. Bir strateji oyununda birden fazla Nash dengesi olabilmektedir. Her oyuncunun sınırlı sayıda saf strateji arasından seçim yapabildiği sınırlı sayıda oyuncuya sahip her oyunun en az bir Nash dengesine sahip olduğu kanıtlanmıştır (Piraveenan, 2019:4).

Nash tarafından geliştirilen sıfır toplamlı oyun yaklaşımında, oyundaki iki veya daha fazla oyuncu, diğer oyuncunun seçimlerini ve seçimlerini değiştirmede hiçbir kazanç olmayacağını bilirse, oyuncuların seçeneklerinden sapmayacağı bulunmuştur. Bu nedenle, bir dizi karar stratejisi olarak Nash dengesi, stratejiyi tek taraflı olarak değiştirerek oyuncuların faydalarını artıramayacağını göstermektedir. Bununla birlikte, gerçek hayat senaryolarında, kazançlar ve kayıplar her zaman o kadar net ve ölçülebilir değildir (Bonau, 2017:8).

\subsection{Oyun Teorisi Stratejileri}

Oyun teorisinin stratejileri; saf strateji ve karma strateji olmak üzere iki kategoriye ayrılmaktadır. Saf strateji oyuncuların oyun stratejilerini tam olarak belirlemektedir. Oyuncunun herhangi bir durum için yapması gereken eylem tanımlanmaktadır. Bir oyuncunun stratejik seti, o oyuncu için mümkün olan bir dizi saf stratejidir. Her 
oyuncunun optimize edilmiş stratejileri vardır ve oyunun değeri tüm oyuncular için aynıdır (Sohrabi ve Azgomi, 2020:60).

Saf strateji, bir oyuncunun farklı stratejilere sahip olsa da kesin olarak belirlenmiş tek bir stratejiyi oynadığı durum olarak ifade edilmektedir (Hoş, 2020:40). Karma Strateji ise, herhangi bir saf stratejiye bir olasılı̆gın atanması olarak tanımlanmaktadır. Bu strateji, bir oyuncunun rastgele saf bir strateji seçmesine izin vermektedir. Olasılıklar sürekli olduğundan, saf stratejiler kümesi sonlu olsa bile, bir oyuncu için sonsuz karma stratejiler bulunmaktadır. Her oyuncu karar vermek için saf stratejiyi veya karma stratejiyi seçebilmektedir. Belirleyici eylemler için saf stratejiler, olasılıksal eylemler için karma stratejiler seçilmektedir (Sohrabi ve Azgomi, 2020:60).

\subsection{Oyunların Sinıflandırılması}

Oyun teorisinde, oyunlar özelliklerine göre çeşitli şekillerde sınıflandırılmaktadırlar. Oyuncuların davranışlarına, oyuna dâhil olan oyuncu sayısına, eylemin zamanlamasına ve oyun aşamalarının sayısına, oyuncuların kazancına, oyuncuların sahip oldukları strateji bilgilerine göre kategorize edilebilmektedir. Oyunların sınıflandırılması ayrıntılı olarak Şekil 2'de gösterilmektedir (Abdel-Raouf vd., 2020:26).

Şekil 2. Oyunların Sınıflandırılması

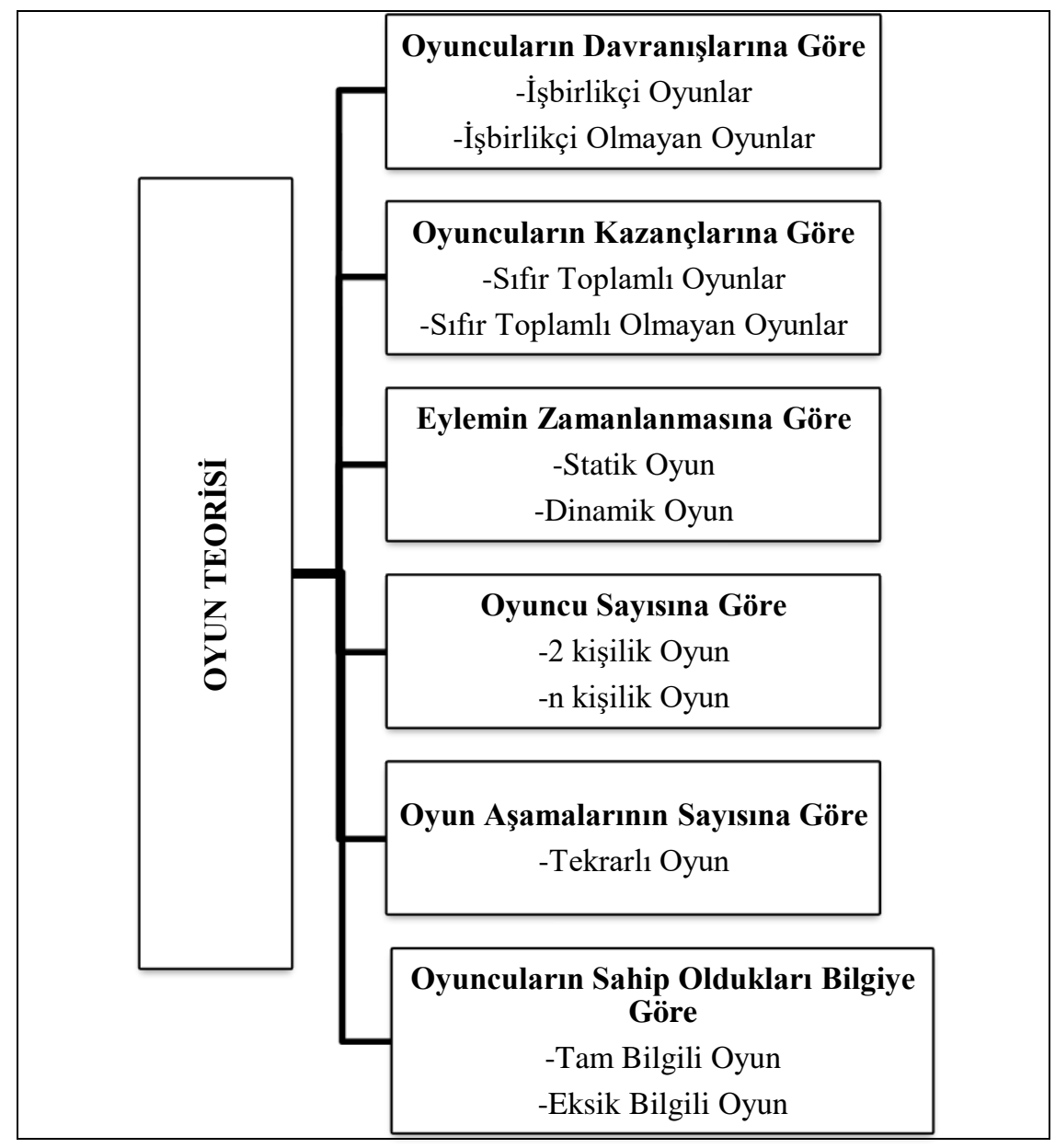

Kaynak: Abdel-Raouf vd., 2020:26.

\subsubsection{Oyuncuların Davranışlarına Göre Oyunlar}

İşbirlikçi oyunlar, oyuncuların yapılandırılmamış etkileşimlerde fayda ve kazançlar yaratmak için koalisyonlarda nasıl işbirliği yaptıklarını örneklemektedir. İşbirlikçi oyunlarda, oyuncular değer yaratmak için işbirliği yapar ve koalisyonlara katılır ya da değer elde etmek için rekabet ederler (Bonau, 2017:8). İşbirlikçi oyunlarda oyuncular, kendi aralarında ittifaklar kurarak oyundan elde ettikleri kârı artırmak için birbirleriyle koordinasyonlu olma yeteneğine sahiptirler. İşbirlikçi oyun teorisi, koalisyonların hangi koşullar altında oluşturulduğunu, her bir koalisyon tarafından kazanılan fayda miktarını ve genel faydanın katılımcılar arasında 
nasıl dağıtıldığını incelemektedir. İşbirlikçi oyunların; politika, ekonomi ve mühendislik ağları gibi çeşitli alanlarda uygulamaları bulunmaktadır (Abdel-Raouf vd., 2020:27).

İşbirlikçi oyunları açıklamak için geliştirilmiş “Mahkumlar Açmazı (Prisoners' Dilemma)" önemli modellemelerden biri olarak belirtilmektedir (Stewart ve Plotkin, 2012:10134). Bu modelin çatışmalı ilişkiler söz konusu olduğunda ve oyuncuların, karşılıklı olarak istenmeyen, bir duruma düşmemek için işbirliği yapması gerektiğinde uyarlanabileceği belirtilmektedir (Elibol, 2017:22).

İşbirlikçi olmayan oyunlar ise, her bir oyuncunun, kazancını en üst düzeye çıkarmak için oyundaki diğer katılımcılardan herhangi biriyle işbirliği veya koordinasyon olmaksızın bağımsız olarak hareket ettiği durumlardır ve karar vericilerin rekabetçi davranışları incelenmektedir. Amaç, ters çıkarları olan oyuncular arasındaki işbirliği eksikliğinin belirli bir stratejik karar verme durumu üzerindeki etkisini ve bunların her birinin elde ettiği fayda üzerindeki etkisini araştırmaktır (Abdel-Raouf vd., 2020:26). İşbirlikçi olmayan oyunlar, oyuncuların karar vermek için diğer oyuncuların seçimleri ve hareketleri hakkındaki bilgileri kullanarak belirli bir süreçte kendi kazançlarını en üst düzeye çıkaran eylemlerini göstermektedir (Bonau, 2017:8).

\subsubsection{Oyuncuların Kazançlarına Göre Oyunlar}

Geleneksel oyun teorisinde, sıfır toplamlı oyun, bir oyuncunun galibiyetinin başka bir oyuncunun kaybıyla sonuçlandığı faydadaki net değişimi sıfır yapan bir oyunu tanımlamaktadır. Oyuncu sayısı sınırlı değildir (Bonau, 2017:8). Satranç, poker ve basketbol gibi birçok spor oyunu sıfır toplamlı oyunlara örnek olarak verilebilirken, gerçek yaşamda nadiren sıfır toplamlı oyun bulunmaktadır. Sıfır toplamlı olmayan oyunlarda ise, tüm oyuncular birlikte kazanabilmekte ya da kaybedebilmektedir. Günlük hayatta ve iş dünyasındaki oyunların çoğu sıfır toplamlı olmayan oyunlardır. Şirketler arasındaki fiyat rekabetleri sıfır toplamlı olmayan oyunlara örnek olarak verilebilmektedir. Sıfır toplamlı olmayan oyunlarda oyuncuların ortak ve çatışan çıkarları bulunmaktadır (Bhuiyan, 2016:114).

\subsubsection{Eylemin Zamanlanmasına Göre Oyunlar}

Statik oyunlar, hiçbir oyuncunun diğer oyuncuların eylemleri hakkında herhangi bir bilgisi olmadığı ve oyuncuların aynı anda strateji seçimlerini yaptıkları eşzamanlı oyun olarak adlandırılmaktadır (Abdel-Raouf vd., 2020:26). Bu nedenle oyuncular karar verirken diğer oyuncuların kararları hakkında bilgi sahibi değildirler (Sohrabi ve Azgomi, 2018:60).

Zaman kavramının oyuncuların seçimleri veya kararları üzerinde hiçbir etkisi yoktur. Statik oyunlara, bir defaya mahsus kapalı teklif açık artırması örnek olarak verilebilmektedir. Oyuncunun bu oyunda bir teklifi vardır ve hiçbir oyuncu diğer oyuncuların teklifleri hakkında herhangi bir ayrıntı bilmez ve en iyi teklifi veren oyuncu, oyunun sonunda oyunun galibi olarak ilan edilmektedir (Abdel-Raouf vd., 2020:26).

Oyun teorisinde statik oyun kapsamında yoğun olarak belirli miktarda paranın iki oyuncu tarafından nasıl paylaşılacağı üzerine kurgulanmış olan ültimatom oyununun literatürde incelendiği görülmektedir (Yalçıntaş, 2015:252). Dinamik oyun ya da ardışı oyun, oyuncuların eylemlerini aynı anda gerçekleştirmedikleri oyun türü olarak tanımlanmaktadır. Oyuncular bir sonraki kararlarında diğer oyuncuların aldığı kararları dikkate almaktadırlar (Sohrabi ve Azgomi, 2018:60).

Dinamik oyunlarda oyuncular, rakiplerinin taktikleri ve eylemleri hakkında az da olsa bilgi sahibi olurlar, böylece birden fazla eylemde bulunabilirler. Bu oyunlarda karar verme sürecinde zaman kavramı çok önemlidir. Dinamik açık artırma, dinamik oyunlara örnek olarak verilebilmektedir. Dinamik açık artırmada teklif verenler, belirli bir emtianın fiyatını birden fazla artırabilirler ve müzayedeyi kazanan en yüksek değerli teklif olmaktadır (Abdel-Raouf vd., 2020:26).

\subsubsection{Oyuncu Sayısına Göre Oyunlar}

Oyuncu sayısına göre genellikle birden fazla oyuncu olmalıdır. Maksimum oyuncu sayısı sonludur. Bir oyuncu; birçok bireyden, şirketten, ortaktan vb. oluşan bir ekip de olabilmektedir. Oyun, tek kişilik, iki kişilik veya nkişilik ( $>2$ ) olarak gruplara ayrılabilmektedir (Bhuiyan, 2016:113). 


\subsubsection{Oyun Aşamalarının Sayısına Göre Oyunlar}

Tekrarlanan oyunlar her aşaması tam bir oyun olan, birkaç tekrarlanan basit oyundan oluşmaktadır. Tekrarlanan oyun, formdaki temel oyunların sadece bir tekrarı olsa da, sonuç oldukça farklı olabilmektedir (Zhang vd., 2010:153). Bir oyunda oyuncunun eyleminin zaman içerisinde tekrarlanması kendi seçimlerini ve diğer oyuncuların seçimlerini etkilemektedir. $\mathrm{Bu}$ etkileşimin süreklilik göstermesi tekrarlı oyunların dinamik oyunların önemli bir parçası olduğunu da göstermektedir (Hoş, 2020:50).

\subsubsection{Oyuncuların Sahip Oldukları Bilgiye Göre Oyunlar}

Tam bilgili oyunlarda, oyundaki her oyuncu tüm oyuncuların stratejilerini ve bu stratejileri uyguladıklarında elde edecekleri kazanç ya da kayıpları tam olarak bilmektedirler (Liang ve Xiao, 2012:473). Tam bilgili oyunlara örnek olarak; satranç, dama ve açık arttırma oyunları verilebilmektedir. Bir oyuncunun diğer oyuncunun hamlesi hakkında bir bilgiye sahip olması rekabet ortamı oluşturmayacağından, genellikle rekabetin olmadığı oyunlar tam bilgili oyunlardır (Hoş, 2020:50).

Eksik bilgili oyunlarda, oyunculardan en az biri tüm oyuncuların stratejilerini uyguladıklarında elde edecekleri kazanç ya da kayıpları bilmemektedir (Liang ve Xiao, 2012:473). Gerçek hayatta karşılaşılan birçok durum oyun teorisi bağlamında oyuncuların birbirleri hakkında tam bilgiye sahip olmadıkları durumlardır. Eksik bilgili oyunlara; ihaleye katılan firmaların verdiği fiyatlar, pazarlık yapan tarafları düşündüğü değerler örnek olarak verilebilmektedir (Hoş, 2020:51).

\subsection{Oyunların Gösteriş Biçimleri}

Oyunların gösteriş biçimleri oyunları doğru anlamak ve analiz etmek için en önemli faktörlerden biri olarak belirtilmektedir. Oyunlar genel olarak; her bir oyuncunun tek bir boyutta mevcut stratejilerini dengelediği analitik veya normal form ve her oyuncunun stratejilerinin bir düğüm dağılımına karşılık geldiği kapsamlı, ağaç grafik biçimi olan yaygın form olarak iki şekilde gösterilmektedir (Georgiou, 2015:13).

- Normal Form: Rekabetçi oyunları temsil eden karmaşık durumlar analiz edildiğinde kullanılmaktadır. Oyuncuların stratejilerinin ve sonucunda elde edecekleri kazanç ya da kayıpların tek bir tabloda gösterildiği biçimdir (Colman, 2016:50). Normal formdaki oyun biçimi oyunculara sunulan stratejilerle ilişkili satır ve sütun konumları ve karşılık gelen kazanç ya da kayıplarla ilişkili içerikleri olan bir oyun matrisi sunmaktadır. Genellikle başka herhangi bir konfigürasyon tam olarak gösterilemediğinden, 2 oyunculu eşzamanlı oyunlar için normal form uygun bulunmaktadır. İki oyuncunun bulunduğu normal formda tasarlanmış bir oyun Şekil 3'de gösterilmektedir (Georgiou, 2015:15).

Şekil 3. Normal Form Örneği

\begin{tabular}{|c|c|c|}
\hline \multirow{2}{*}{ Oyuncu 1 } & \multicolumn{2}{|c|}{ Oyuncu 2 } \\
\cline { 2 - 3 } & $(2,5)$ & $(4,6)$ \\
\cline { 2 - 3 } & $(1,7)$ & $(8,9)$ \\
\hline
\end{tabular}

Kaynak: Hoş, 2020:43.

- Yaygın Form: Oyun teorisinde yaygın formda oyunu gösterebilmek için en uygun yöntemin oyun ağacı olduğu belirtilmektedir. Oyun ağacının köşeleri, seçim noktalarına karşılık gelmektedir ve ait oldukları oyuncuların isimleriyle etiketlenmektedir. Oyun ağacının dalları ise oyuncuların aralarından seçim yaptıkları seçenekleri temsil etmektedir. Oyun ağacının son noktaları, her oyuncunun oyunun kurallarına göre hareket ettikten sonra ulaşılan sonuçları temsil etmektedir (Colman, 2016:49). Yaygın form, oyuncular stratejilerini seçtikçe oyunun nasıl geliştiğini gösteren bir durum geçiş diyagramı olarak da tanımlanmaktadır. Yaygın form biçimi, hareket zincirlerini ve çözüm yollarını tanımlamak için çok uygun yollar sunmaktadır. İki oyuncunun bulunduğu ve her oyuncunun iki stratejisinin olduğu bir oyun Şekil.4'de gösterilmektedir (Georgiou, 2015:15). 
Şekil 4. Yaygın Form Örneği
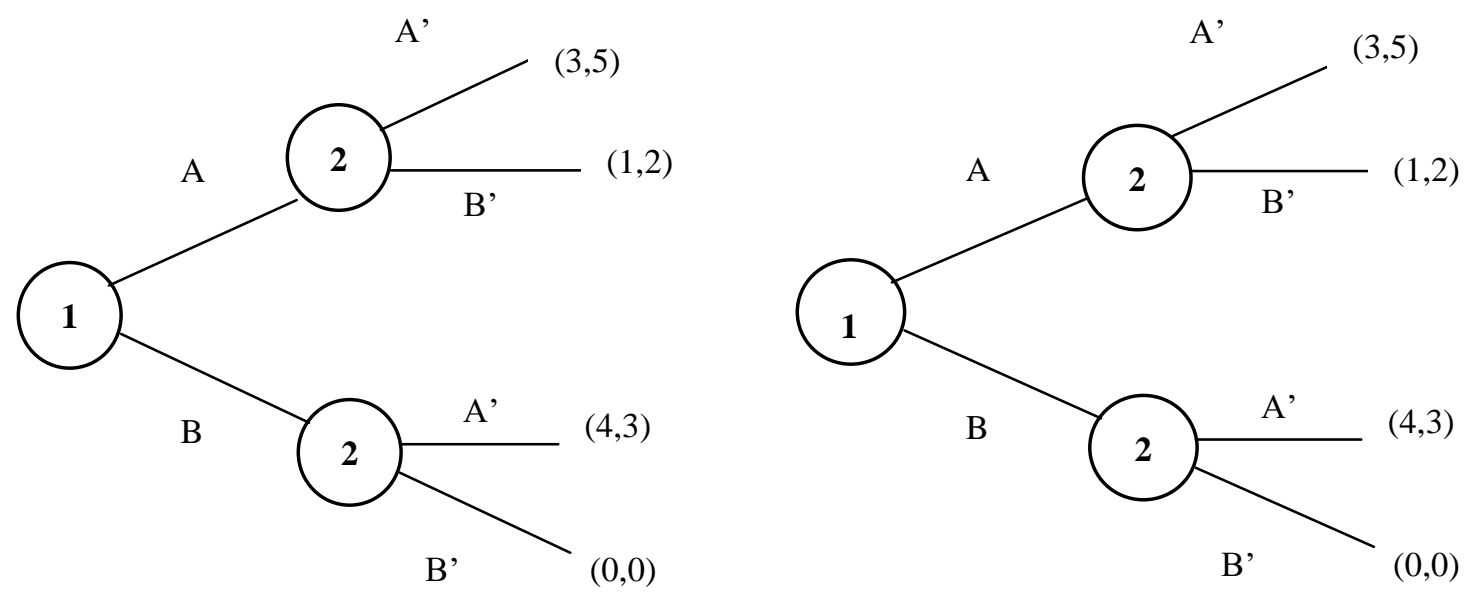

Kaynak: Georgiou, 2015:15.

\subsection{Oyunların Sonucu ve Çözümü}

Oyuncuların çeşitli stratejilerle seçerek ilerledikleri varsayımı çerçevesinde oyunun sonucuna veya denge noktasına Nash dengesi denilmektedir. Nash dengesi, oyun içerisinde rakiplerin planladıkları stratejileri değiştirseler bile hiçbir zaman elde ettikleri sonuçtan daha iyisini elde edemeyecekleri nokta olarak tanımlanmaktadır. Oyuncuların oyunda yer alan diğer oyuncuların stratejilerinde herhangi bir farklılık olmadığ 1 sürece en iyi kazancı sağladıkları nokta olarak da belirtilmektedir (Demirci ve Palanc1, 2020:533). Denge kavramı, oyun türlerine göre farklı çözüm yöntemleri olan oyun teorisinde önemli bir yere sahiptir. Öncelikle tam bilgili statik oyunların çözümü için bulunan Nash dengesi daha sonra diğer oyun türlerinin çözümü için geliştirilmiştir (Hoş, 2020:55).

Literatürde, Nash dengesinin geliştirilmiş hali olan ve eksik bilgili oyunların çözümünde kullanılan Mükemmel Bayes dengesinden söz edilmektedir. Eksik bilgili oyunlarda sadece gelecek için beklentiler değil oyuncuların sezgi, inanç, tahmin ve gözlemlerinin de etkili olduğu belirtilmektedir (Deniz ve Akbaş11, 2018:241). Nash dengesi, oyuncuların inançlarını açıkça ifade etmezken, Mükemmel Bayes dengesi, oyuncuların diğer oyuncuların denge stratejileriyle tutarlı inançlara sahip oldukları durum olarak açıklanabilmektedir (Teng, 2013:1).

\section{VEKÂLET TEORİSI VE OYUN TEORİSININ İLISSKILENDİRILMESI}

Tarafların bireysel çıkarlarını maksimize etmeyi amaçlayan fırsatçılık, herhangi bir faaliyetle ilgili olarak vekilin kritik bilgilere sahip olduğu, asilin ise bu bilgilere sahip olmadığı; diğer bir ifade ile asimetrik bilginin (Pouryousefi ve Frooman, 2017: 168) bulunması halinde ortaya çıkmaktadır. Asimetrik bilgi oyun teorisi perspektifinde değerlendirildiğinde, oyunculardan en az birinin diğer oyuncuların stratejileri hakkında tam bilgiye sahip olmadıkları ve "eksik bilgili oyun" olarak nitelendirilen tür ile açıklanabilmektedir. Bilgi üstünlüğüne sahip tarafların, bu üstünlüğü değerlendirerek bazı faydalara ulaşması firsatçılık kavramı ile bağdaşmaktadır.

Karşılıklı çıkarların gözetildiği geniş bir sözleşme alanına dayanan vekâlet teorisinde firsatçı davranışların önlenmesine ilişkin birtakım tedbirlerin alınması gerekmektedir. Stratejik rasyonalite anlayışının özüne bakıldığında firsatçılık kavramının oyun teorisi ile anlaşılması mümkün görülmektedir. Bu kavramın merkezinde eylemin değerini belirleyen şeyin eylemin ürettiği sonuçlar olduğu poptülası yer almaktadır. Bu durum, rasyonel bir vekilin sonuçlardan bağımsız olarak doğrudan eyleme ilişkin; bağlılık, sosyal normlara uygunluk ve ahlaki kurallara saygı gibi deontik kısıtlamaları ortadan kaldırabilir. Bireysel çıkarların uzun veya kısa vadede nasıl kazanç veya kayıplara dönüşeceği ise değişkendir.

Öte yandan oyun teorilerinde yer alan mahkûmlar açmazı (prisoners' dilemma) matrisine göre bireysel çıkarları amaçlayan kararlar çoğunlukla örgütün çıkarlarına da hizmet etmeyecektir. Zira tekrarlanan oyunlarda bireyin 
bir diğeri ile iş birliği içerisinde olması daha kazançlı görülmektedir. Bu bağlamda asil-vekil ilişkisinin uzun vadeli veya süreğen dönem için kurulduğu varsayımı ile bireysel rasyonelitenin, fırsatçıllı̆ı en iyi tercih olmaktan çıkardığı söylenebilir.

Yine vekâlet teorisinde Gizli Bilgi Modeli ve Gizli Eylem Modeli olmak üzere iki modelden bahsedilmektedir. Gizli bilgi modeli, işe alımlarda vekilin istenen özelliklere sahip olup olmadığı hakkında asilin bilgi sahibi olmadığı durumu ifade etmektedir. Gizli eylem modeli ise, vekâlet teorisinin temelini oluşturan, asil ve vekil hakkında bazı varsayımlarda bulunmaktadır. Buna göre her iki tarafın da motivasyonunun kendi çıkarlarından kaynaklandığı (firsatçı davranış eğiliminin söz konusu olduğu), asilin eksik bilgiye sahip olduğu koşullarda çalıştığı, gerçekleşen sonuçların vekil ile birlikte çevresel faktörlerden etkilendiği, vekilin ise risk altında olduğu durumlardan bahsedilebilmektedir (Babacan ve Eriş, 2006:97).

Gizli eylem modelinin bazı varsayımlarının tarafların motivasyonun fırsatçı eğilimlerden kaynaklanması, oyun teorisinde oyuncuların kazancını arttırmak için diğer oyunculardan bağımsız olarak hareket ettiği işbirlikçi olmayan oyunlar ile açıklanabilir. Öte yandan asilin eksik bilgiye sahip olduğu koşullarda çalışması durumu ise oyun teorisi kapsamında eksik bilgili dinamik oyunlardan Mükemmel Bayes dengesinin çözümleyebileceği bir varsayımdir.

Analitik oyun teoremlerinden ültimatom oyunu da vekalet teorisinde olduğu gibi bireylerin çıkarcı olduğu ve kendi kazançlarını maksimize etmeye eğilim gösterdiklerini varsayar. Bir pazarlık oyunu olarak kurgulanan ültimatom oyununda belirli miktarda bir paranın oyuncular tarafından nasıl paylaşılacağının ölçülmesi amaçlanır. İlk oyuncu, ilgili miktarın nasıl paylaşılacağına dair diğer oyuncuya bir teklif götürür. İkinci oyuncunun teklifi kabul etmesi halinde, para ikinci oyuncunun teklif ettiği oranda paylaşılırken; teklifin reddedilmesi halinde her iki oyuncu da hiçbir kazanç sağlayamaz. Elbette, ikinci oyuncunun herhangi bir teklifi reddetmek için hiçbir olumlu teşviki yoktur. Zira önerilen hiçbir pay, sıfır kazançtan daha kötü değildir. Dolayısıyla, teklifi reddetmek cezai sonucu olan bir eylemdir ve buna sebep olan tehdit sekansal rasyonelitenin ${ }^{2}$ ortaya çıktığı bir çeşit mutabakattır. Sonuç olarak bu teorem, birinci oyuncunun ikinci oyuncuya mümkün olduğunca az teklif ettiği (bir anlamda firsatçı davrandığı) bir payı seçmesi gerektiğini önermesi nedeniyle vekâlet maliyetlerine bir çözüm olması pek mümkün görülmemektedir.

Temel asil-vekil modelini matematiksel gösterim ile ifade etmek gerekirse; Asil P (principal), vekil ise A ile (agent) gösterilmek üzere, A'nın iki alternatif eylem olan $\mathrm{x}$ ve $\mathrm{y}$ arasında seçim yapabileceğini ve bu eylemlerin iki farklı sonucunun, $\mathrm{X}$ ve Y'nin gerçekleştirilmesine katkıda bulunacağını varsayılsın. Bu iki eylemden hangisini tercih ederse etsin A'nın bir tür ödeme karşılığında P'nin çıkarlarını temsil etmesi beklenmektedir. P ve A tarafları arasında asimetrik bilgi söz konusu ise P, A'nın hangi tutumda bulunduğu ile ilgilenmek yerine eylemin sonucuna yani P'ye karşı olan sorumluluğunu yerine getirip getirmediğine bakacaktır. Bu doğrultuda A'nın P'ye karşı sorumluluğu, ilgili görevi yerine getirmekten oluşacak ve bunu nasıl gerçekleştirdiği göz önünde bulundurulmayacaktır. Öte yandan X veya Y sonuçlarının tercih edilmesi, A'nın eylemleri tarafından belirlenmeyecek, yalnızca bu durumdan etkilenecektir. Özetle X ve Y sonuçlarından hangisinin gerçekleşeceği kararını $\mathrm{P}$; sonucun hangi yolla elde edileceğinin kararını ise A verecektir. Bu modelde, farklı argümanlara sahip yardımcı program işlevlerinde de görülebileceği gibi, P'nin çıkarlarının A'nın çıkarlarıyla eşleşmediği bir durum söz konusudur.

$$
\begin{array}{ll}
\text { P'nin refah maksimizasyonu: } & \mathrm{U}_{\mathrm{P}}=\mathrm{U}(\mathrm{a}, \mathrm{b}, \mathrm{c}) \\
\text { A'nın refah maksimizasyonu: } & \mathrm{U}_{\mathrm{A}}=\mathrm{U}(\mathrm{d}, \mathrm{e}, \mathrm{f})
\end{array}
$$

P'nin kendi refahını maksimize etmek istediğini ve iki olası sonuç olan $\mathrm{X}$ ve Y ile ilişkili faydaların $\mathrm{U}_{P}{ }^{X}$ ve $\mathrm{U}_{P}{ }^{Y}$ olduğu varsayılsın. $\mathrm{U}_{P}^{X}>\mathrm{U}_{P}^{Y}$ olması halinde $\mathrm{P}, \mathrm{X}$ sonucunu tercih edecektir. Tercihi yapacak olan $\mathrm{P}$ olduğundan, $\mathrm{U}_{A}{ }^{x}>\mathrm{U}_{A}{ }^{y}$ ve $\mathrm{U}_{A}{ }^{x}<\mathrm{U}_{\mathrm{A}}^{\mathrm{y}}$ durumunda dahi A, x eylemini tercih etmek zorunda kalacaktır. $\mathrm{U}_{P}{ }^{X}>\mathrm{U}_{P}{ }^{Y}$ ve $\mathrm{U}_{A}{ }^{x}>\mathrm{U}_{A}{ }^{y}$ halinde; $\mathrm{P}, \mathrm{X}$ sonucunu, $\mathrm{A}$ ise $\mathrm{x}$ eylemini seçecek ve böylece görevin kötüye kullanılması ihtimali ortadan kalkacaktır. Ancak $\mathrm{U}_{P}{ }^{X}>\mathrm{U}_{P}{ }^{Y}$ ve $\mathrm{U}_{A}{ }^{x}<\mathrm{U}_{A}{ }^{y}$ koşulu altında; $\mathrm{P}, \mathrm{X}$ sonucunu tercih ederken, A bireysel çıkarları için y eylemini seçecektir ki bu da fırsatçılık kavramı bağlamında birtakım suiistimalleri doğuracaktır (Groenendijk, 1997:211-212).

2 Kreps ve Wilson'ın geliştirmiş olduğu sekansal rasyonelite kavramına göre her karar, oyunun geri kalanı için optimal bir stratejinin parçası olmalıdır. Bu gereklilik, eksik bilgili oyunlarda Savage'ın belirsizlik altında seçim aksiyomlarına uyumludur. Her safhada oyuncunun sonraki stratejisi, diğer oyuncuların önceden yapmış olduğu ancak gözlemlenmemiş seçimleri de dahil olmak üzere tüm belirsiz olayların olasılıklarının değerlendirmelerine göre optimal olmalıdır (Kreps ve Wilson, 1982:863). 
Zira $\mathrm{U}_{P}^{X}>\mathrm{U}_{P}{ }^{Y}$ ve $\mathrm{U}_{A}{ }^{x}<\mathrm{U}_{A}{ }^{y}$ koşulu; A'nın üstlendiği sorumluluklar ve bireysel çıkarlar arasında bir çatışmaya sebep olacaktır. Yükümlülükleri yerine getirme eylemlere yön veren etkili bir saik olmakla beraber, tek başına belirleyici değildir. A'nın amacının bireysel çıkarları maksimize etmek olduğu bir koşul altında; P'ye karşı sorumluluklarını yerine getirmek, A için sadece bir yan kısıttan ibaret olacaktır. Bu durumda A belirlenmiş kısıtlar çerçevesinde görevini, çıkarları doğrultusunda gerçekleştirecektir. Sonuç olarak A, P'nin beklentisi altındaki yükümlülükleri gerçekleştirmek şartı ile bireysel faydasını maksimize edecek (zimmet, rüşvet, vb.) hileli ve ahlaki olmayan eylemlerde bulunabilecektir (Telatar, 2004:195).

\section{SONUÇ VE ÖNERILER}

Vekâlet teorisinde asil-vekil ilişkisi içerisinde bulunan taraflardan birinin belirli nitelik ve/veya nicelik kapsamında diğerinden daha az bilgiye sahip olması bilgi asimetrisini ortaya çıkarmaktadır. Bir diğer ifade ile asimetrik bilgi, ilgili vekâlet ilişkisi için hazırlanmış sözleşmenin imzalanmasından önce veya sonra; söz konusu etkileşimin doğurduğu davranışlara ilişkin tarafların mülkiyetindeki bilgi farklılığını ifade etmektedir. Gerçekte hangi eylemlerin ortaya konulduğuna dair, vekilin asili bilgilendirmesinin vekâlet firsatçıllğı gibi sorunların önüne geçtiği düşünülmektedir. Ancak vekilin eylemlerini izleyebilmek için gereken maliyetlerin karşılanamadığı durumlarda yoğunlaşan bilgi asimetrisi, tarafların bencillik ve firsatçılık eğilimlerinin kontrolden çıkmasına ve amaç birliğinden sapmaya neden olmaktadır.

Teorinin temel varsayımlarına göre, vekil ve asilin önce bireysel çıkarlarını maksimize etmeye odaklandıkları, tarafların motivasyonunun bu doğrultuda sağlandığı, dolayısıyla bazı durum veya eylemleri bu çıkarlar maksadıyla yönettikleri düşünülmektedir. Bilgi paradigmasının modern sosyoekonomik sistemde etkili olması ile gelişmeye başlayan firsatçılık kavramı; bireylerin kendi çıkarları doğrultusunda karşı tarafı aldatma eğilimi göstermeleri, bilgi ve gerçeğin manipüle edilmesi, verilmiş sözleri yerine getirmeme veya getiriyor gibi görünme ve kimi zaman hileli eylemleri ifade etmektedir.

Çalışmanın üçüncü bölümünde bahsedilen ilişkilendirmeye göre vekâlet firsatçılığının oyun teorisi çerçevesinde açıklanabildiği görülmüştür. Literatürde henüz bu iki teoriyi birlikte inceleyen bir ölçek bulunmamaktadır. Ancak çeşitli sektörlerde ortaya çıkan vekâlet fırsatçılığı sorunlarının oyun teorisi ile çözümlenebileceği düşünülmektedir. Örneğin, bazı ürün pazarlarında nitelikleri güvenilir ürünlerin kalitesine dair tüketicinin tam bilgiye sahip olmadığı durumlar söz konusu olabilmektedir.

Tüketiminden sonra dahi gözlenemeyen kalite özelliklerine sahip ürünler pazarda zaman içinde kendilerine daha fazla yer bulabilirken; üretici yanlış kalite iddiasında bulunarak asimetrik bilgiyi fırsatçı bir davranışa dönüştürebilmektedir. Zira vekâlet teorisi kapsamında asil-vekil ilişkisi bulunan taraflardan üreticinin (vekil) sorumlu olduğu denetsel kuruluşların (asil) üretici hakkında tam bilgiye sahip olmaması da üreticinin fursatçı davranışları tercih etmesine olanak sağlamaktadır. Bu koşulun, eksik bilgili oyun teorisi ile analiz edilebileceği öngörülmektedir. Ancak çalışmada belirtildiği üzere kimi koşullarda oyun teorisinin vekâlet sorunlarını açıklayabilmesi veya çözüme ulaştırabilmesi mümkün görülmemektedir. Yine de oyun teorisinin farklı senaryoların olası sonuçlarını karşılaştırarak optimal stratejileri belirleyebilme fırsatı tanıması, yönetici ve stratejistlerin gerek vekalet maliyetlerinin engelleyebilmeleri gerek mevcut şartlar dahilinde stratejik düşünme süreçlerini derinleştirererek organizasyona maksimum kazanç sunabilmeleri ve organizasyon kültürünü bu çerçevede güncelleyebilmeleri açısından oldukça önemlidir. Bahsi geçen iki teori arasındaki ilişkilendirmelerden hareketle bu çalışmanın ilgili konularda araştırma yapacaklara yol gösterici olması umulmaktadır.

\section{KAYNAKÇA}

ABDEL-RAOUF, Osama, ELSISY, Mohamed A. ve KELASH, Eslam Fathy Saber (2020), "Survey of Game Theory Applications in Electrical Power Micro-Grid Systems", International Journal of Computer Applications, S.177(37), ss.25-34.

AKERLOF, George A. (1970), "The Market for "Lemons": Quality Unvertainty and the Market Mechanism", The Quarterly Journal of Economics, S.84(3), ss.488-500.

ATAMAN, Göksel (2009), İşletme Yönetimi, Türkmen Kitabevi, İstanbul, 3. Bask1.

BABACAN, Muazzez ve ERİ̧̧, Engin Deniz (2006), "Pazarlamada Vekâlet Teorisi ve Kavramsal Bir Model Geliştirme”, Hacettepe Üniversitesi İktisadi ve İdari Bilimler Fakültesi Dergisi, S.24(1), ss.89-110. 
ARSLAN, Buket ve ÇETİN, Elif - Vekâlet Teorisinde Fırsatçılık Kavramı ve Oyun Teorisi Arasındaki İlişki

BAKER, Rose M. (2019), "The Agency of the Principal-Agent Relationship: An Opportunity for $H R D^{\prime \prime}$, Advances in Developing Human Resources, S.21(3), ss.303-318.

BHUIYAN, Bellal Ahmed (2016), “An Overview of Game Theory and Some Applications”, Philosophy and Progress, S.59(1-2), ss.111-128.

BONAU, Sarah (2017), “A Case for Behavioural Game Theory”, Journal of Game Theory, S.6(1), ss.7-14.

COLMAN, Andrew M. (2016), Game Theory And Experimental Games: The Study Of Strategic Interaction, Elsevier Publisher, Amsterdam.

DEMIRCI, Esranur ve PALANCI, Osman (2019), "Ulusal Yazında Oyun Teorisi Üzerine Genişletilmiş Bir Literatür Taraması”, Mehmet Akif Ersoy Üniversitesi Sosyal Bilimler Enstitüsü Dergisi, S.11(29), ss.530-549.

DENIZ, Ünal ve AKBAȘLI, Sait (2018), “Oyun Teorisi Bağlamında Eğitim Örgütlerinde Karar Verme”, Eğitim Yönetimi Araştırmaları (Ed. C. T. Uğurlu, K. Beycioğlu, S. Koşar, H. Kahraman, F. K. Şermin), Sivas Cumhuriyet Üniversitesi Yayın1, Sivas, ss.238-245.

DONALDSON, Lex (1990), "The Ethereal Hand: Organisational Economics and Management Theory", Academy of Management Review, S.15(3), ss.369-381.

DU MOUTIER, Michel Lyonnet (2010), "Financing the Eiffel Tower: Project Finance and Agency Theory", Journal of Applied Finance, S.1, ss.127-142.

EISENHARDT, Kathleen M. (1988), “Agency and Institutional Theory Explanations: The Case of Retail Sales Compensation", The Academy of Management Journal, S.31(3), ss.488-544.

EISENHARDT, Kathleen M. (1989), “Agency Theory: An Assessment and Review”, Academy of Management Review, S.14(1), ss.57-74.

EKINCİ, Bilge Timuçin (2017), “Asil-Vekil Arasındaki Kayırmacılı̆̆ın Vekâlet Maliyetleri İle İlişkisi”, Manas Sosyal Araştırmalar Dergisi, S.6(2), ss.73-96.

ELİBOL, Mehmet (2017), "Oyun Teorisi ve Toplu Pazarlık Stratejileri”, Yayımlanmamış Yüksek Lisans Tezi, Namık Kemal Üniversitesi Sosyal Bilimler Enstitüsü, Tekirdağ.

ERREN, Thomas C., SHAW, David M. ve MORFELD, Peter (2016), "Analyzing The Publish-or-Perish Paradigm With Game Theory: The Prisoner's Dilemma And A Possible Escape”, Sci Eng Ethics, S.22(5), ss.1431-1446.

GASSENHEIMER, Jule B., BAUCUS, David B. ve BAUCUS, Melissa (1996), "Cooperative Arrengements among Entrepreneurs: An Analysis of Opportunism and Communication in Franchise Structures", Journal of Business Research, S.36(1), ss.67-79.

GAUR, Sanjaya S., BATHULA, Hanoku ve SINGH, Deeksha (2015), "Ownership Concentration, Board Characteristics and Firm performance", Management Decision, S.53(5), ss.911-931.

GEORGIOU, Harris V. (2015), "Elements of Game Theory-Part I: Foundations, Acts And Mechanisms", arXiv, ss.1-37.

GHOSHAL, Sumantra (2005), "Bad Management Theories Are Destroying Good Management Practices", Academy of Management Learning \& Education, S.4(1), ss.75-91.

GROENENDIJK, Nico (1997), "A Principal-Agent Model of Corruption”, Crime, Law and Social Change, S.27(3/4), ss.207-229.

HAMILTON, Robert D. ve KASHLAK, Roger J. (1999), "National Influences on Multinational Corporation Control System Selection”, Management International Review, S.39(2), ss.167-189.

HANNES, Sharon (2007), "Reverse Monitoring: On the Hidden Role of Employee Stock-Based Compensation", Michigan Law Review, S.105(7), ss.1421-1451.

HOŞ, Safa (2020), "Rekabetçi Önceliklere Göre Tedarikçi Değerlendirmede Oyun Teorisi Yaklaşımı", Yayımlanmamış Doktora Tezi, Hitit Üniversitesi Sosyal Bilimler Enstitüsü, Çorum. 
ISLAM, Muhammed Z., ISLAM, Mohammed N., BHATTACHARJEE S. ve ISLAM, A. (2010), "Agency Problem And The Role of Audit Commitee: Imlications For Corporate Sector in Bangladeh", International Journal of Economics and Finance, S.2(3), ss.177-188.

JENSEN, Michael, C. ve MECKLING, William H. (1976), "Theory of the Firm: Managerial Behaviour, Agency Costs and Ownership Structure", Journal of Financial Economics, S.3(4), ss.305-360.

JENSEN, Michael C. ve SMITH, Clifford (2000), "Stockholders, Managers and Creditor Interests: Applications of Agency Theory", A Theory of the Firm: Governance, Residual Claims and Organizational Form (Ed. E. Altman, M. Subrahmanyam), Harvard University Press, ss.95-131.

JI, Ang ve LEVINSON, David (2020), "A Review of Game Theory Models of Lane Changing", Transportmetrica A: Transport Science, S.16(3), ss.1628-1647.

KURLAND, Nancy B. (1995), “Ethics, Incentives, and Conflicts of Interest: A Practical Solution”, Journal of Business Ethics, S.14(16), ss.465-475.

LIANG, Xiannuan ve XIAO, Yang (2013), "Game Theory for Network Security", IEEE Communications Surveys \& Tutorials, S.15(1), ss.472-486.

MAHER, Maria ve ANDERSSON, Thomas (2000), "Corporate Governance: Effects on Firm Performance and Economic Growth", Organisation for Economic Co-Operation and Development, LSN: Corporate Governance International (Topic), ss.1-41.

McCOLGAN, Patrick (2001), Agency Theory and Corporate Governance: A Review of the Literature from A UK Perspective, University of Starthclyde, Department of Accounting and Finance Working Paper, United Kingdom.

MESJASZ, Czeslaw (2008), "Ekonomik Güvenlik”, Uluslararası İlişkiler Dergisi (Çev. Yelda Demirağ), S.5(18), ss.125-150.

MIRRLEES, James A. (1999), "The Theory of Moral Hazard and Unobservable Behaviour: Part I", The Review of Economic Studies, S.66(1), ss.3-21.

NEZARAT, Amin ve DASTGHAIBYFARD, Gholam Hossein (2015), "Efficient Nash Equilibrium Resource Allocation Based on Game Theory Mechanism in Cloud Computing by Using Auction", Plos One, S.10(10), ss.1-29.

OSNABRUGGE, Mark Van (2000), "A Comparison of Business Angel and Venture Capitalist Investment Procedures: An Agency Theory-Based Analysis", Venture Capital, S.2(2), ss.91-109.

PIRAVEENAN, Mahendra (2019), "Applications of Game Theory in Project Management: A Structured Review and Analysis", Mathematics, S.7(9), ss.1-31.

POURYOUSEFI, Sareh ve FROOMAN, Jeff (2017), "The Problem of Unilateralism in Agency Theory: Towards A Bilateral Formulation", Business Ethics Quarterly, S.27(2), ss.163-182.

ROSANAS, Josep M. (2008), "Beyond Economic Criteria: A Humanistic Approach to Organizational Survival”, Journal of Business Ethics, S.78, ss.447-462.

ROSS, Stephen A. (1973), "The Economic Theory of Agency: The Principal's Problem", The American Economic Review, S.63(2), ss.134-139.

SEYİDOĞLU, Halil (2006), İktisat Biliminin Temelleri, Güzem Can Yayınları, İstanbul.

SHAPIRO, Susan P. (2005), “Agency Theory”, Annual Review Sociology, S.31(1), ss.263-284.

SHARMA, Anurag (1997), "Professional as Agent: Knowledge Assymetry in Agency Exchange", The Academy of Management Review, S.22(3), ss.758-798.

SOHRABI, Mohammad K. ve AZGOMI, Hossein (2020), "A Survey on The Combined Use of Optimization Methods And Game Theory", Archives of Computational Methods in Engineering, S.27(1), ss.59-80.

STEWART, Alexander J. ve PLOTKIN, Joshua B. (2012), “Extortion And Cooperation in The Prisoner's Dilemma", Proceedings of the National Academy of Sciences, S.109(26), ss.10134-10135.

TELATAR, Funda (2004), İktisat Politikası, İmaj Yayınları, Ankara. 
TENG, Jimmy (2013), Is Perfect Bayesian Equilibrium a Subset of Nash Equilibrium, American University of Ras Al Khaimah Publisher, Ras al Khaimah.

TURABOĞLU, Tuncay (2004), "Vekalet- Temsil- Problem ve Maliyetler", Ekonomik Yaklaşım, S.15(51), ss.109-124.

WOO, Carolyn Y., WILLARD, Gary E. ve DEALLENBACH, Urs S. (1992), "Spin-Off Performance: A Case of Overstated Expenctations?", Strategic Management Journal, S.13, ss.433-447.

YALÇINTAŞ, Murat (2015), "Ekonomik Karar Almada Adalet ve Oyun Teorisi", Maliye Finans Yazıları, S.29(103), ss.247-274.

ZHANG, He, SU, Yuelong, PENG, Lihui ve YAO, Danya (2010), “A Review of Game Theory Applications in Transportation Analysis", International Conference on Computer and Information Application, IEEE Publisher, Tianjin - CHINA, ss.152-157.

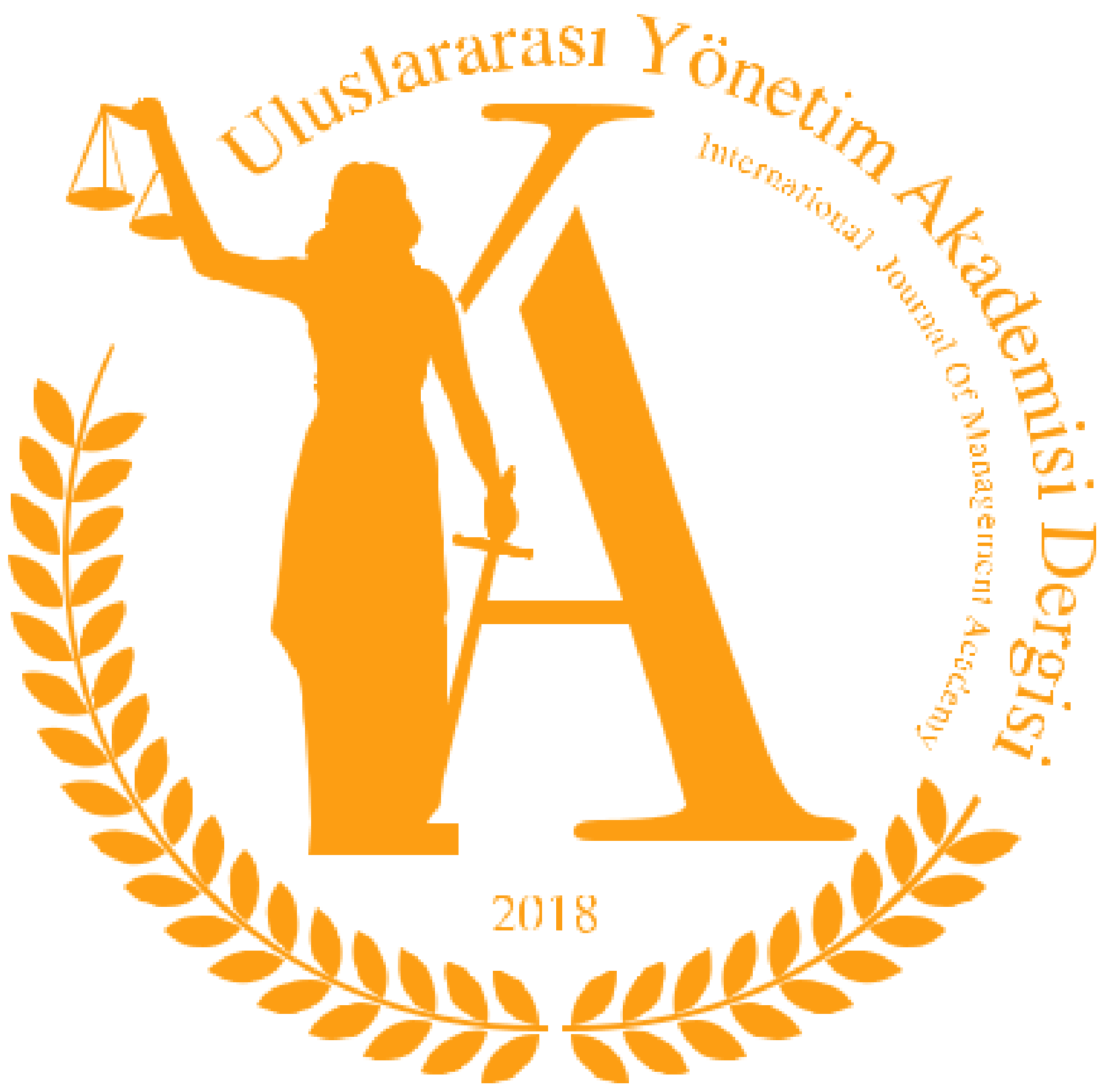

